\title{
The Integration of Character Education and Intercultural Competence in German Learning Process
}

\author{
Ajeng Dianing Kartika ${ }^{1, *}$ Muhammad Nur Ashar Asnur ${ }^{2,}$ Piet Sumoukil ${ }^{3}$
}

${ }^{1,2,3}$ Universitas Negeri Surabaya

*Corresponding author.Email: ajengkartika@unesa.ac.id

\begin{abstract}
Learning foreign languages in the 4.0 era is currently a demand in education, especially higher education level. By mastering foreign languages, students are expected to be able to develop knowledge and build international communication. Language and culture are two inseparable entities. When a person learns a foreign language, he inevitably also learns the culture in which the language is used. In order to realize a holistic foreign language learning, intercultural-based learning is the right solution. The success of foreign language learning will also be influenced by how far the cultural elements of the target language can be understood and integrated in learning. Learning a foreign language, in this case German, requires students to know and understand German culture. The polarization that appears in several aspects of Indonesian and German culture makes students more critical in understanding the culture of the two countries. The intercultural-based learning process enables the students to have intercultural competencies which are the basis for adapting and communicating between cultures. Some aspects of intercultural competence which is in line with character education as follows. (1) Expansion of cultural insight (das Kulturbild) by respecting foreign cultures (das Fremde) based on an understanding of one's own culture (das Eigene). This will lead students to continue to appreciate and love the culture and noble values as an Indonesian nation. (2) Learners will be guided to have the ability to tolerate and empathize with something "foreign" and have the ability to be careful about negative stereotypes.

Keywords-character education, intercultural competence, german learning
\end{abstract}

\section{INTRODUCTION}

Character education has been initiated by the government and has become mainstream at various levels of education. Character education is the focus in the world of Indonesian education. The realm of formal education is not only a means for students to hone their academic skills but also to build and shape their character. Character education is important for the advancement of moral education in Indonesia. character is a characteristic of a person or group of people that contains values, abilities, moral capacity, and resilience in the face of difficulties and challenges (Character Education Partnership, 2010)

Singla (2009) stated that the character traits should include, but are not limited to, courage, good judgment, integrity, civility, kindness, perseverance, responsibility, tolerance, selfdiscipline, respect for school personnel, responsibility for school safety, service to others and good citizenship. A person's "character" refers to the disposition and habits that determine the way that a person normally responds to desires, fears, challenges, opportunities, failures and successes. We describe the character of a person in reference to moral judgments about the worthiness of a person. This is what causes the importance of character building for the advancement of the younger generation as agents of change in society.

One of the efforts to build better character in the future is to integrate character education in learning. Character education can be implemented through integration in the learning process, including in german as foreign language classroom. Today the foreign language a requirement for Indonesian intellectual society, so that the learning of foreign languages at various levels of education receive special attention and have many takers. In learning German at the university level, it is not only aimed at producing students who are skilled in German, but also students who are able to understand German culture because actually language and culture are 2 entities that cannot be separated. Learning German means having to understand the culture as well.

According to Schein in Setiawan (2011), there are several things related to the concept of culture, namely: (a) the regularity of human behavior when he interacts with others, which includes the language used, customs and traditions, rituals performed; (b) group norms, namely standards and values that develop within a group; (c) the values that a group wants to achieve and are known to the public; (d) philosophy 
or belief adopted by a community; (e) the rules of the game, which members of that community must follow; (f) climate, i.e. what shared feelings about the environment in which a person is located; (g) inherent skills that are passed on to the younger generation; (h) thinking habits, mental models and/or linguistic paradigms, which are the perceived cognitive framework as a reference in building perceptions, thinking and the language used by the group; and (i) shared meaning, namely the emergence of understanding created by groups when they interact with one another.

The last few decades have also developed ideas to complement foreign language learning with an intercultural approach so that the terms interkultureller Fremdsprachenunterricht (teaching foreign languages with intercultural approach) and interkulturelles Lernen (Intercultural learning) have emerged. This approach clearly emphasizes the integration of cultural aspects in language learning. This is partly based on the opinion of Benjamin Lee Whorf (Calne, 2005) who has proposed a theory of linguistic relativity. He emphasizes the diversity of conceptual content in various languages and suggests that this diversity arises from cultural characteristics. In addition, this approach has become broadly discussed because sociological facts in Europe show that Europe is very multicultural and in a foreign language class it is often found that students come from various cultural backgrounds.

By applying an intercultural approach in learning German, students are required to learn German by understanding the real context of German culture. In this way they will have multicultural competence and the ability to contrast German culture and Indonesian culture and identify the good sides of each culture that can be imitated in everyday life.

\section{METHODS}

\subsection{Character Building}

Berkowitz (2002) stated that character is an individual'set of psychological characteristic that affect that person's ability and inclination to function morally. Simply put, character is comprised of those characteristics that lead a person to do the right thing or not to do the right thing. Character is the result of psychological process which entails the capacity to think about right and wrong, experience moral emotions (guilt, emphaty, compassion), engage in moral behaviors (sharing, donating to charity, telling the truth), believe in moral goods, demonstrate an enduring tendency to act with honesty, altruism, responsibility, and other characteristics that support moral function.

Aristotle defines character as the right relationship of life both to others and to oneself. This relationship presents control of oneself, of one's own desire to do what is right for others (Lickona, 1991: 50). Furthermore, he said that character is values that operate and act to respond to situations and consist of knowledge about morals, moral feelings, and moral behavior. From this definition, character education is how these character values are processed in learning interactions so that they become competencies, desires, and habits. This is the essence of character, namely values have become an inherent part and people do it spontaneously without thinking.

Character is a synergy between knowledge (moral knowing), feeling (moral feeling) and action (moral action). Our knowledge of moral values/goodness, such as: awareness of the importance of goodness (moral awareness), knowledge of good values (knowing moral values), recognizing various views (perspective-taking), having good reasoning (moralreasoning), making decisions (decision making), and selfknowledge (self-knowledge) will give birth to good feelings/natures (moral feeling). Among the traits that emerge are: awareness (conscience), self-respect (self-respect), empathy (empathy), love of goodness (loving the good), selfcontrol (self-control), and humility (humility). After the knowledge and feelings about the values of goodness, the character will bring up actions in the form of competence, will, and good habits. (Lickona, 2001)

Characters are classified into 6 pillars that are universal (Josephson, 2011). These pillars can be observed in the following table.

\begin{tabular}{|c|c|c|}
\hline Num. & Character Pillars & Sub-category \\
\hline 1 & Trustworthyness & $\begin{array}{l}\text { Honesty, integrity, reliability, } \\
\text { loyalty }\end{array}$ \\
\hline 2 & Respect & $\begin{array}{l}\text { Civility, dignity, } \\
\text { autonomy, tolerance, } \\
\text { and acceptance }\end{array}$ \\
\hline 3 & Responsibility & $\begin{array}{l}\text { Accountability, pursuit of } \\
\text { excellence, diligence, continuous } \\
\text { improvement, self restraint, }\end{array}$ \\
\hline 4 & Fairness & Process, impartially, equity \\
\hline 5 & Caring & \\
\hline 6 & aship & \\
\hline
\end{tabular}

Table 1. Character Pillars

From these pillars, it can be seen that character building involves aspects of knowledge, feelings and actions. Therefore, character building cannot necessarily be taken for granted. Everything requires a process as well as the involvement of external parties, one of which is the university, as an education unit.

University level as higher education is an educational unit providing higher education that is obliged to take part in the formation of the nation's character. Higher education educators are professional educators and scientists with the main task of transforming, developing, and disseminating science, technology, and art through education, research, and community service (Tridarma Perguruan Tinggi). Professional tertiary educators have functions as teachers, educators, and trainers so that they can develop the cognitive, affective, and psychomotor aspects of students. This is the entrance for character education to be implemented at the university level in Indonesia. Character development is very important to be carried out by universities and their stakeholders to become a foothold in the implementation of character education in universities 
The purpose of character education is basically to encourage the birth of good human beings, who have attractive personalities, are ethical, unpretentious, honest, intelligent, caring, and tough. Growing and good character will encourage students to grow with the capacity and commitment to do the best things and do everything right and have a purpose in life.

Factors that influence success or failure in the process of applying character education include human instincts that have existed since birth, habit factors that are done repeatedly, then there are hereditary factors that inherit traits from parents to their children and environmental factors that exist in nature and the social environment. All these factors are interconnected and influence each other in all human nature and actions in everyday life

\subsection{Character Education}

According to Beller and Leersen (2007) character education has three main functions, namely 1) formation and development function, 2) reinforcement and repair function, and 3) as a filter. Character education functions so that students are able to develop the their potential to think well, have a good heart, and behave well. Beside that character education has a great possibility to improve and strengthen the role of families, education units, communities and the government to take responsibility and participate in developing the potential of their citizens. In this paper will focus on the role of university, specifically german department as a education unit which integrate character education within the learning process.

Foreign language learning in Indonesia, including German, is also bound by the mandate contained in Law number 20 of 2003 concerning the National Education System, especially in $3^{\text {rd }}$ article which stated that -Pendidikan nasional berfungsi mengembangkan kemampuan dan membentuk watak serta peradaban bangsa yang bermartabat dalam rangka mencerdaskan kehidupan bangsa, bertujuan untuk berkembangnya potensi peserta didik agar menjadi manusia yang beriman dan bertakwa kepada Tuhan Yang Maha Esa, berakhlak mulia, sehat, berilmu, cakap, kreatif, mandiri dan menjadi warga negara yang demokratis serta bertanggung jawabl.

\subsection{Intercultural Approach in Foreign Language Learning}

The intercultural approach is considered as a continuation of the communicative approach, although it sometimes overlaps. The purpose of learning this approach is not only to develop communicative competence, but also to develop an understanding of culture and something foreign (das Fremde). Students are expected to be able to understand their own culture and foreign cultures better (Pauldrach, 1992). Students also need to have an understanding of the culture of the target language, so that they can enter the stage of communicating with a positive attitude about interlocutors whose cultures are different (Chick, 2009).

The ideal goal of learning foreign language is international understanding, in which students mastering the language and also the culture at the same time. Intercultural approach in foreign language learning has the basis that the success of communication that occurs between communicators who come from two different cultures is not only determined by the mastery of linguistic aspects, in terms of grammatical structures and socio-pragmatics, but also the ability to capture, understand and have empathy for the culture of communication partners (Pauldrach, 1992).

Weimann (1993) menyatakan bahwa perbandingan budaya (Kulturvergleich) harus menjadi salah satu perhatian dalam proses pembelajaran Bahasa asing berbasis interkultural, termasuk dalam pembelajaran Bahasa Jerman. From these various opinions, it can be concluded that learning foreign languages today is not enough just to learn foreign languagesdevelop language skills in the target language, but also must develop the ability in learners to be able to understand foreign cultures (das Fremde) which is the background based on a good understanding of their own culture (das Eigene). The hope is that when the learner is in an intercultural situation, he or she can communicate with his or her communication partner properly and correctly. Byram (Maijala, 2008) then proposed the concept which he calls intercultural speakers, which more or less means as someone who is able to communicate well interculturally. Byram proposed this terminology instead of a term that is often referred to as the main goal of learning a foreign language, namely being able to communicate like a native speaker.

Furthermore Kaikkonen (2002:6) explains that foreign language learning should encourage students to be able to achieve what is known as intercultural communication competence (interkulturellen Kommunikationskompetenz). This competence, in addition to containing language skills in the target language, is also related to the affective aspects of the learner such as Sensibilisierungsvermögen, Empathievermögen, Respektierungsfähigkeit, interactive Fähigkeit, Ambiguitätstoleranz, und Fähigkeit zum Perspektivewechsel. This has been confirmed by Bredella/Delanoy (1999:13) that in learning a foreign language with an intercultural perspective, there are inherently goalseducation, such as tolerance and the ability to empathize. The next important task is to build sympathetic relationships between different cultures and dismantle negative stereotypes.

\section{RESULTS AND DISCUSSION}

As previously explained, character education in Indonesia aims to form the nation's children who have good morals and are able to act on noble values correctly. The question that arises is whether foreign language learning with an intercultural perspective can play a role as a place to sow moral "seeds" in learners? This question can be answered by comparing aspects of the noble values that exist in character education and the pedagogical goals of learning foreign languages with an intercultural perspective.

First, in foreign language learning that applies intercultural approach, it is intended that students have the ability to understand something "foreign" (foreign culture), including foreign values. This can only be achieved if the students also recognize and understand their own culture. Thus, a good understanding of one's own culture becomes the basis for 
moving to understand foreign cultures through the language being studied. The formation of self-identity as a nation will indirectly be formed. This is in line with the first character pillar of the character pillars, namely the character of love for God and all of His creation because all the cultural diversity and natural wealth that help shape the culture of the Indonesian nation cannot be separated from God's hands. In addition, in the current era of globalization, the possibility that students in Indonesia to leave their cultural environment and move and enter a new cultural environment is very large, for example when studying or working abroad. Of course we want them not to lose their identity as Indonesians and their love for Indonesia.

Learning a foreign language with an intercultural perspective has a goal related to the affective area of the learner, namely developing empathy and tolerance for something "foreign" or anything that comes from outside the cultural circle. The ability of empathy and tolerance, if developed properly, will help learners to also be tolerant in society. Sociological facts in Indonesia show that the Indonesian nation consists of various ethnic groups that are very multicultural so that the ability to empathize and tolerance is important to be developed in learners. This is in accordance with the ninth pillar of character, namely tolerance, peace, and unity as well as with the second pillar of Josephson (2011), namely respect which contains the values of tolerance and acceptance.

In learning a foreign language with an intercultural perspective, it intends to eliminate negative stereotypes about foreign cultures within the learner. Unfounded stereotypes often lead to misunderstandings between communicators from two different cultures. The ability to eliminate these negative stereotypes will be used in everyday life. As said before, that Indonesian society is very multicultural so that all children of the nation must be careful in thinking or acting when dealing with other people who come from cultural communities, or even another religion. Not yet lost from our memories, some of the riots that hit Indonesia could not be separated from the inability of some of the nation's children to eliminate negative prejudices against other people who came from outside their cultural circle. This excessive negative prejudice is one of the causes in the minds of some people, negative stereotypes against other ethnic groups or religions are recorded.

\subsection{Intercultural Approach in German As Foreign Language Learning}

One of the recommended ways to integrate character education in foreign language learning is to use discussion techniques. With discussion techniques, foreign language students who learn German will be invited to think critically in observing the cultural aspects contained in foreign language discourses that are studied based on an understanding of their own culture. In the following, some examples will be presented.

First example will be taken from the Sprachbeherschung (Lesen, Schreiben, Sprechen, Hören) classroom. In learning the Sprechen 3 course using the Netzwerk A2 Kursbuch book, there is chapter 4 with the theme Große und kleine Gefühle.
Learning begins with an introduction to the vocabularies used in the chapter. The page starts with 5 pictures consisting of a graduation party (der Schulabschluss), the first day of school (der erste Schultag), a company anniversary celebration (der Jubiläum der Firma), a man who won a medal (der erste Platz), the birth of a baby (die Geburt von einem Kind), the wedding day (die Hochzeit), and one of which shows a picture of a woman holding a driver's license (Führerschein).
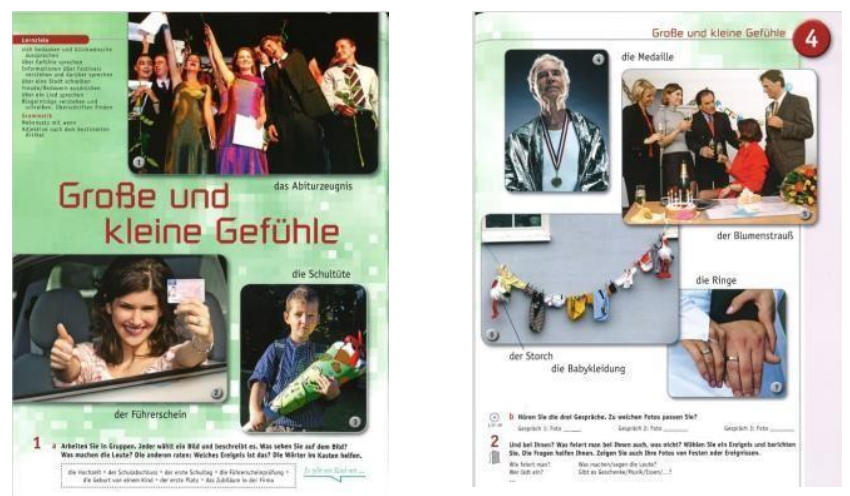

Picture 1. Screenshoot of Learning Material 1

The vocabulary recognition process here is done through the practice of matching pictures with the information provided. This process is also accompanied by a discussion of the events in the photos. Here it turns out that students are asking why having a driving license and passing the driving license exam is a happy moment. This happens because generally in Indonesia many people use the services of brokers to take care of sims without the need to go through an exam. In Germany there are no brokers and it is not possible to get a driver's license without an exam. German society is aware of the significance of sim ownership which must be accompanied by a test as a form of validity of sim ownership. From this explanation, the students emphasized that the German people have more disciplined characters than the Indonesian people in the context of managing SIMs and implementing the rules.

The next example is taken from the course Deutsch 3 where students have entered the intermediate level of German or level B1. The topics studied are already more complex than t A1 and A2 levels. Learning using the book Netzwerk B1 is combined with other supporting materials from the internet. In chapter 5 with the theme Umweltfreundlich. This chapter discusses the environment, how the environmentally friendly concept is applied by Germany and the efforts made to save energy. One of the materials studied for speaking competence is expressing opinions (Meinung äußern) as shown in the following picture. 


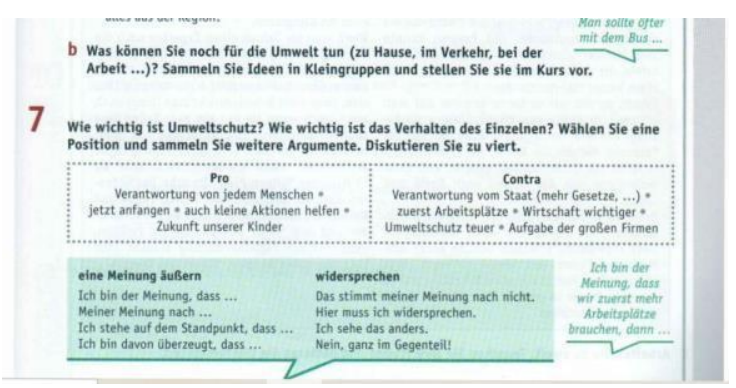

Picture 2. Screenshoot of Learning Material 2

In task 7 students were asked to conduct group discussions about rhe importance of environmental protection and the role of the community in environmental protection. There are two options, namely the pro on the opinion that environmental protection is the shared responsibility of all elements of society and the cons that support the opinion that environmental protection is the responsibility of the government. Here, students are required to conduct research first by reading articles on environmental protection or preservation, what can be done by the community to protect the environment, and are there laws that systematically accommodate environmental conservation efforts. After the discussion process was over, students were given a stimulus to compare environmental conservation in Germany and Indonesia. The aims of this comparing is to raise their awareness of environment protection and imitate the positive things that the German people do to maintain the cleanliness and sustainability of their environment. The real effort that the German people do daily, for example with a very detailed waste sorting system and also reducing the use of motorized vehicles in everyday life. Students were then given additional material about the waste sorting system in Germany, the habbit of the people to keep the environment clean and asked to express their opinion about the system.

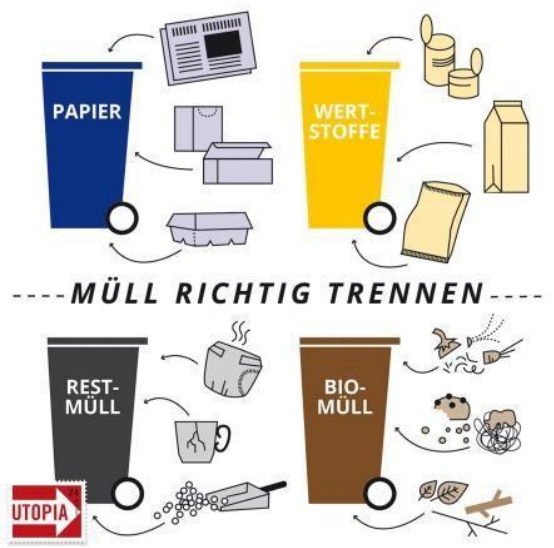

Picture 3. Waste Sorting System in Germany

Unconsiously, students have learned that German society is very concerned about the environment and discipline in disposing of waste in the places provided according to the color of the trash cans that have been determined. Caring for the environment can be realized through disciplined habits of disposing of waste. The character values obtained in this study are discipline and care for the environment created by God.

In addition to the two themes that have been explained, there are many other themes that can also be integrated with character education, such as the theme of the concept of relationship and marriage in Germany which is also very different from Indonesia. Like most western countries, Germany also legalizes living together without marriage, in stark contrast to our eastern customs which require marriage to be able to live together. In this context, students can conduct an in-depth analysis of the noble values of eastern Indonesian culture and make comparisons with western cultural values and discuss how to continue to maintain the moral values of eastern Indonesia in the midst of many influences from outside cultures.

Through discussions like this, foreign language learners in this case German learners are still guided to see foreign cultural events that are encountered based on the noble values that exist in Indonesian society. A process like this will strengthen the learner's self-identity as an Indonesian nation with all the ideal cultural values it has.

\section{CONCLUSION}

Character education in higher education aims to improve the quality of education implementation and outcomes that lead to the achievement of the formation of character and noble character of students in a complete, integrated, and balanced manner, according to graduate competency standards. Through character education, students are expected to be able to independently improve and use their knowledge, studyand internalize the values of character and noble character so that they are realized.

The implementation of foreign language learning in Indonesia has two major responsibility, namely developing the ability to communicate in the foreign language being studied as well as being responsible for building the character of the students. This task can be carried out by applying foreign language learning using an intercultural approach. Learning a foreign language with an intercultural perspective aims to develop communicative competence as well as intercultural competence. Some aspects of intercultural competence that are in line with character education are as follows. (1) Expansion of cultural insight by respecting foreign cultures based on an understanding of one's own culture. This will lead students to continue to appreciate and respect the culture and noble values of the Indonesian people. (2) Learners will be guided to have the ability to tolerate and empathize with something "foreign" and have the ability to be careful about negative stereotypes

\section{ACKNOWLEDGMENT}

We would like to thank the reviewers and expert readers who have been willing to provide valuable input for the improvement of this article. Hopefully this article can add insight for readers about the importance of character development through foreign language learning. 


\section{REFERENCES}

[1] Beller, Manfred \& Leerssen, Joep. Imagology. The Cultural Construction and Literary Representation of National Characters. A Critical Survey. Amsterdam, New York: Rodopi. 2007

[2] Berkowitz, Marvin W. "The Science of Character Educatioan" in Bringing in a New Era in Character Education. Editor: Damon, William. Stanford: Hoover Institution Press. 2002

[3] Bredella, Lothar \& Delanoy, Werner (Hrsg.). Interkultureller Fremdsprachenunterricht: Das Verhältnis von Fremdem und Eigenem. Tübingen: Narr. 1999.

[4] Byram, Michael. Teaching and Assessing Intercultural Communicative Competence. Clevedon: Multilingual Matters. K. Elissa, "Title of paper if known," unpublished. 1997
[5] Chick, J. Keith. Intercultural Communication: Sociolinguistics and Language Teaching. 2009.

[6] Hinkel, E. (Ed.). Culture in second language teaching and learning. Cambridge: Cambridge University Press. 2007.

[7] Lickona, Thomas. What Is Good Character? And How We Can Develop It in Our Children. Journal of Gale Education, Religion and Humanities Lite Package. p.239. Lickona, Thomas. 2003. The Content of Our Character: Ten Essential Virtues. 2001. http://www.charactereducation.info/Articles/ TheContentofOurCharacter.pd.£ downloaded 6/11/2020.

[8] Pauldrach, Andreas. "Eine unendliche Geschichte: Anmerkungen zur Situation der Landeskunde in den90er Jahren" in Fremdsprache Deutsch- Zeitschrift für den Praxis des Deutschunterrichts: Landeskunde. Juni, 1992. München: Verlag Klett Edition Deutsch. 